\title{
НАЛОГ НА ДОХОДЫ ФИЗИЧЕСКИХ ЛИЦ КАК ИНСТРУМЕНТ ГОСУДАРСТВЕННОГО РЕГУЛИРОВАНИЯ ЭКОНОМИКИ: РОССИЙСКИЙ И МЕЖДУНАРОДНЫЙ ОПЫТ
}

\author{
(c) 2020 Чернов Сергей Борисович \\ кандидат экономических наук, доцент, \\ доцент кафедры мировой экономики и международных экономических отношений \\ Государственный университет управления, Россия, Москва \\ Email: chernov_s_b@mail.ru \\ (c) 2020 Захарова Александра Вячеславовна \\ кандидат экономических наук, доцент, \\ доцент кафедры бухгалтерского учета, аудита и налогообложения \\ Государственный университет управления, Россия, Москва \\ Email: avzakharova@mail.ru
}

Налог на доходы физических лиц раскрывается как инструмент государственного регулирования экономики. Рассмотрены вопросы соблюдения принципов налогообложения. Установлена связь между использованием прогрессивной шкалы налоговых ставок и снижением социальной напряженности в обществе. Доказано, что дифференциация налоговых ставок способствует автоматической стабилизации макроэкономики. Выделяется связь между несовершенством механизма налогообложения и появлением теневой экономики. Обсуждается зарубежный опыт применения прогрессивного налогообложения и обосновывается необходимость его использования. Обосновывается переход к ступенчатой шкале налоговых ставок, введения необлагаемого налогом минимума доходов и повышенной налоговой ставки на неоправданно высокие сверхдоходы.

Ключевые слова: налоги, принципы налогообложения, налоговая ставка, государственное регулирование, автоматические стабилизаторы, теневая экономика.

Вектор налоговых реформ в последние годы был направлен на снижение налоговой нагрузки на бизнес за счет расширения льгот и преференций, создания эффективной системы администрирования и налогового контроля, изменения стратегии развития налогообложения имущества, расширения мер по противодействию уклонению в низконалоговых юрисдикциях, отмене не способствующих экономическому росту и социальному эффекту от применения льгот. В отношении налогообложения физических лиц реализованные направления налоговой политики затронули следующие аспекты: введение кадастровой стоимости имущества в качестве налогооблагаемой базы и изменение механизма уплаты налога на имущество, уточнение порядка предоставления имущественных налоговых вычетов по налогу на доходы физических лиц, введение налога на профессиональный доход и изменение порядка уплаты налога на доходы физических лиц (НДФЛ) индивидуальными предпринимателями в части авансовых платежей. Исполнение указанных мер способствовало в основном реализации фискальной функции налогов с физических лиц.

Действующая в России система налогообложения за более чем 30 лет своего существования с момента принятия Налогового кодекса, на наш взгляд, не обоснованно отказалась от таких важных элементов социально-экономической направленности как необлагаемый минимум доходов и прогрессивная шкала ставок. Как следствие, индекс Джини в 1998 году при применении прогрессивной системы налогообложения доходов составлял $39,4 \%(0,394)$, а в $2018-$ при пропорциональной системе $-41,1 \%(0,411)$. Так, в сочетании с невысоким уровнем реальных денежных доходов населения, основным источником уплаты налога является заработная плата трудоспособного населения с низким и средним уровнем дохода, а 15,2\% получали в 2017 году заработную плату ниже 14 тыс. руб. в месяц, а в 2019 году 64,9\% имели заработную плату в размере от 14 до 50 тыс. руб., а численность населения с доходами ниже величины прожиточного минимума составляла в 2018 году 12,9\% [1]. 
НДФЛ является одним из основных источников бюджета Российской Федерации, теоретически относится к прямым налогам и исчисляется в процентах от совокупного дохода физических лиц, полученного в денежной и в натуральной форме. В соответствии со ст. 13 Налогового кодекса России НДФЛ относится к федеральным налогам, поэтому механизм его расчета на территории страны единый. Однако НДФЛ зачисляется не в федеральный, а преимущественно в региональный и в меньшей степени местный бюджеты.

В настоящее время ст. 224 Налогового кодекса России установлены различные ставки НДФЛ в зависимости от вида дохода физических лиц, например, на выигрыши и призы - 35\%; на доходы нерезидентов - 30\%; на дивиденды от долевого участия в деятельности российских организаций - 15\%; на доходы резидентов от осуществления трудовой деятельности - $13 \%$. Таким образом на данный момент в России не используются положительные возможности прогрессивных ставок НДФЛ для государственного регулирования экономики и длительное время применяются пропорциональные налоговые ставки. В результате НДФЛ рассчитывается в фиксированном проценте от налогооблагаемой базы независимо от ее объема и не учитывают реальную объективную способность налогоплательщика к уплате налога.

Сторонники пропорциональной системы указывают на то, что она удобна в администрировании, где основная часть доходов облагается у источника их выплаты, а к так называемым «пассивным» доходам, не связанным с затратами физического и умственного труда применяются повышенные ставки, обеспечивая минимальное вмешательство в личную жизнь налогоплательщика, в то время как прогрессивная система налогообложения доходов требует особого администрирования, поскольку совокупный доход и окончательные налоговые обязательства могут быть рассчитаны только при подаче декларации.

Однако это доказательство легко оспаривается в связи с развитием цифровизации работы налоговых органов. Уже в настоящее время имеется опыт создания и совершенствования специализированных электронных сервисов и информационных систем, облегчающих налоговое администрирование и контроль [2].С помощью«Личного кабинета налогоплательщика» можно решать отдельные вопросы администри- рования НДФЛ, например, предлагается его использовать при предоставлении стандартного налогового вычета для ветеранов боевых действий [3].

Прогрессивное налогообложение должно коснуться лишь только той части налогоплательщиков, которая получает большие и сверхдоходы. Поэтому наладить налоговый контроль будет не так затруднительно, как это первоначально представляется. Следует также добавить, что налоговое администрирование не цель государственного регулирования экономики, а всего лишь его средство. Поэтому необходимо не только развивать цифровизацию в налоговой сфере, но и расширять налоговое администрирование, обеспечивая контроль над доходами и расходами в реальной экономике, в которой помимо легальных участников участвуют субъекты теневого рынка.

На первый взгляд, пропорциональные налоговые ставки представляются предпочтительнее, так как они:

1. Обеспечивают равенство налогоплательщиков. Однако с учетом достижений теории раннего маржинализма можно сделать прямо противоположный вывод о том, что за видимым равенством скрывается глубокое неравенство в налогообложении домашних хозяйств, получающих дифференцированные доходы. Субъекты, получающие меньшие доходы, после уплаты налога по одинаковой ставке, испытывают большую фискальную нагрузку, так как предельная полезность каждой денежной единицы для них сравнительно намного выше.

2. Позволяют сохранить большую часть своего дохода высоко обеспеченным российским гражданам для последующего его инвестирования в национальную экономику. Однако в данном случае забывают отметить возможность вывода этих средств в иностранную валюту, офшоры и роста паразитического потребления в зарубежных поездках.

3. Обеспечивают стабильность налоговой системы. Однако при этом забывают отметить то обстоятельство, что в современном мире государство должно проводить два вида фискальной политики. В рамках дискреционной фискальной политики государство путем изменения законодательства меняет налоговые ставки с целью увеличения занятости и реального валового внутреннего продукта либо контроля над инфляцией. Но такая фискальная политика: 
- во-первых, имеет большой временной лаг от времени принятия решения до его реализации;

- во-вторых, содержит большие политические риски и издержки, связанные с прохождением закона по инстанциям его принятия;

- в-третьих, не обеспечивает автоматического изменения НДФЛ и поступающих за счет этого налога доходов в региональные и местные бюджеты.

Отсутствие гибкости и оперативности в фискальной политике препятствует выработке мер, направленных на обеспечение устойчивого экономического роста, и вынуждает осуществлять меры государственного регулирования экономики исключительно в так называемом «ручном» режиме. Поэтому необходима недискреционная фискальная политика, основывающаяся на действующем законодательстве и предусматривающая встроенные автоматические стабилизаторы экономики. Указанные стабилизаторы включают в себя на ряду с другими элементами прогрессивные налоговые ставки, которые независимо от текущих решений законодательных и исполнительных органов власти выполняют роль автоматических компенсаторов, сглаживающих негативные социально-экономические явления.

4. Привлекают зарубежных инвесторов в российскую экономику. Однако не следует забывать, что существуют множество других, и чаще всего более значимых факторов, сдерживающих инвестиционную активность иностранных акторов.

5. Сокращают соблазн ухода в теневую экономику топ-менеджеров, от действий которых зависит установление уровня оплаты труда в организациях. Данная гипотеза основана на фокусировании исследователей только на размер налоговой ставки, который, по данной точке зрения, выступает единственным фактором, определяющим размеры доходов государственного бюджета и объемы теневой экономики. Однако величина налоговой ставки не является единственным мотивом к налоговым неплатежам. Наравне с этим, следует учитывать уровень наказания неплательщиков налогов, правоприменительную практику, качество выполнения государством своих функций и налоговую культуру граждан.

Укрывательство доходов от налогов свойственно не только субъектам экономической деятельности в Российской Федерации. Например, государственный бюджет Испании каждый год недополучает налоги в размере 20-23 процентов ВВП [4]. В числе неплательщиков налогов числятсякак крупные предприятия, имеющие в своём штате квалифицированных бухгалтеров и юристов и за счёт этого использующие двойную бухгалтерию и регистрацию бизнеса в офшорных зонах, так и малые и средние организации, привлекающие не оформленных официально работников и представляющие фальшивые документы для обоснования своей убыточной деятельности и сокращения налогооблагаемой базы. Но несмотря на это в развитых странах мира применяется прогрессивная шкала налоговых ставок, например, в Испании налоговые ставки на доходы физических лиц варьируется в диапазоне от 19\% до 48\% [5]. В Италии также применяется прогрессивная шкала налоговых ставок, намечено уменьшение налога на доходы малообеспеченных граждан [6].

Согласно выводам классической школы, экономический человек, руководствуясь собственными эгоистическими интересами, поступает так, как ему выгодно. Следовательно неплатежи налогов происходят в следствии материальной заинтересованности их неплательщиков. Такая материальная заинтересованность может возникать у части субъектов экономики при любой ставке НДФЛ, даже установленных на минимальном уровне. Поэтому ориентация только на уровень налоговой ставки в деле противодействия теневым экономическим отношениям не даст ожидаемого эффекта.

6. Обеспечивают такой принцип налогообложения, как умеренность, часто описываемый посредством кривой Лаффера. Однако зависимость между ставками налога и доходами государственного бюджета рассматривают без возможного влияния других значимых факторов, которые влияют на налоговое поведение домашних хозяйств [7]. Следует отметить, что под влиянием, например, увеличения ответственности за совершаемые налоговые преступления, вид кривой Лаффера будет изменяться в сторону роста доходов государственного бюджета. Поэтому в целях усиления контроля за налогоплательщиками в Испании отслеживают динамику энергопотребления, движение средств на банковских счетах и крупные расходы [4]. В Германии материально вознаграждают информаторов о наличии счетов немецких граждан в Швейцарии, а 
также применяется закон о явке с повинной, в соответствии с которым нарушитель добровольно уплачивает налог и штраф, а государственные органы обязуются хранить тайну о доходах раскаявшегося гражданина [8].

В качестве безусловного минуса пропорциональной ставки НДФЛ можно отметить огромную дифференциацию доходов в обществе. Согласно статистическим данным за 9 месяцев 2019 г. на 10\% наиболее обеспеченных граждан России приходилось 29,5\% общей суммы всех денежных доходов в обществе, в то время как на $10 \%$ наименее обеспеченных - только 2,1\% [9]. Естественно, что лица, неспособные обеспечить получаемыми доходами или низкой заработной платой свои необходимые жизненные потребности, могут удовлетворять их за счет других членов своего домашнего хозяйства либо путем перехода в теневой сектор экономики в качестве теневых предпринимателей, наемных работников и теневых потребителей[10]. Значительное социально-экономическое расслоение общества подрывает веру в социальную справедливость и эффективность государственного регулирования, служит причиной участия части населения в теневой экономической деятельности и затягивания государственных и муниципальных служащих в коррупционные схемы.

Прогрессия, наоборот, предполагает налогообложение совокупного дохода с увеличением ставок в зависимости от его величины. При этом обязательным условием является применение необлагаемого минимума доходов, что исключает из числа плательщиков лиц с низким уровнем доходов, делая их более социально защищенными. К этому следует добавить, что прогрессивная шкала налога на доходы физических лиц обладает и другими положительными качествами, к которым можно отнести:

1. Сокращение бюджетного дефицита за счет увеличения налогообложения сверхдоходов, что представляет особую актуальность в условиях снижения доходов государственного бюджета от реализации российской нефти на внешних рынках.

2. Уменьшение социально-экономического неравенства между различными группами населения, что улучшит криминогенную ситуацию в обществе.

3. Реализацию фактического равенства людей в налогообложении, так как пропорциональное налогообложение не учитывает то, что при одинаковой ставке расходы на обеспечение необходимых жизненных потребностей составляют в доходе различную долю, что приводит к снижению уровня жизни граждан с небольшими доходами и его увеличению для высокодоходных групп населения. В социально - ориентированном обществе принцип равномерности налогообложения подразумевает применение прогрессивных ставок, а для этого необходимо введение необлагаемого минимума доходов и введение повышенной налоговой ставки на неоправданно высокие сверхдоходы.

Президент России В.В.Путин отметил, что его задевает и коробит ситуация с высоким уровнем зарплат топ-менеджеров крупных корпораций с государственным участием [11]. Объясняется такой перекос в оплате труда ситуацией на международном рынке, где для таких специалистов установлены большие вознаграждения. Однако в оплате труда врачей, учителей, военнослужащих и многих других работников государственного сектора экономики данный подход к оплате труда почему-то не применяется. Представляется, что для восстановления принципа равенства в налогообложении можно было бы использовать международный опыт прогрессивного налогообложения получаемых сверхдоходов.

4. Обеспечение устойчивости экономической системы в целом. Зарубежные системы налогообложения доходов, как правило, стараются учесть национальные традиции, демографические особенности, принцип равномерности с помощью прогрессивных ставок, применения льгот и семейного налогообложения. Например, подоходный налог в США оплачивается на федеральном, региональном (штаты) и местном (город, округ) уровнях, при этом ставки подоходного налога на каждом уровне свои. На федеральном уровне применяются прогрессивные ставки подоходного налога, которые в настоящее время устанавливаются в пределах от 10 до 37\% от уровня налогооблагаемого дохода [12]. Такие ставки подоходного налога выступают одним из главных встроенных стабилизаторов экономики США, автоматически сглаживающих возникающие в макроэкономике такие негативные социально-экономические явления, как рецессия и безработица.

5. Повышение уровня налогового администрирования в совокупности с усилением внимания на необоснованные расходы домашних 
хозяйств в элитарном сегменте служит фактором обеспечения контроля государственными органами над соответствием расходов граждан их доходам, что чрезвычайно важно в условиях противодействия отмыванию грязных денег и другого имущества, полученных в результате незаконной деятельности, а также финансированию терроризма.

Таким образом, при проведении реформирования налогообложения физических лиц необходимо учитывать влияние этих изменений на социально-экономические процессы. Несмотря на присущие всем налогам фискальной и регулирующей функций, социальная функция находит своё отражение, в большей степени, в налогах с населения, в частности при налогообложении доходов с физических лиц. Следовательно, критерием оценки эффективности НДФЛ с позиции социальной направленности служит его способность решать задачи оптимального перераспределения доходов. Сбалансированная налоговая политика способствует решению многих задач государства и учитывает фискальные интересы и вопросы развития общества, а в современной ситуации введение прогрессивной шкалы обложения будет способствовать снижению социальной напряженности в обществе. Первый шаг по введению прогрессивного налогообложения уже сделан. С 1 января 2021 г. при налогообложении доходов физических лиц в сумме, превышающей 5 млн. руб., будет применяться повышенная налоговая ставка в размере $15 \%$ [13].

\section{Библиографический список}

1. Неравенство и бедность // Федеральная служба государственной статистики. - URL: http://old.gks.ru/wps/ wcm/connect/rosstat_main/rosstat/ru/statistics/population/poverty/\# (дата обращения: 10.03.2020).

2. Захарова А.В., Чернов С.Б.К проблеме национальной безопасности и государственного налогового контроля в УсловияХ цИфровИзациИ экономикИ // ШАГ В БУДУЩЕЕ: ИСКУССТВЕННЫЙ ИНТЕЛЛЕКТ И ЦИФРОВАЯ ЭКОНОМИКА: SMART NATIONS: ЭКОНОМИКА ЦИФРОВОГО РАВЕНСТВА. Материалы III Международного научного форума. - М.: Государственный университет управления,2020. С. 99-105.

3. Чернов С.Б., Захарова А.В. Вопросы применения налогового вычета в деле патриотического воспитания граждан // ОБЩЕСТВО. ДОВЕРИЕ. РИСКИ. Материалы Ежегодного Международного форума.- М.: Государственный университет управления, 2020.- С. 481-486.

4. Испания начала новый «крестовый поход» против неплательщиков налогов. - URL: https://www.dw.com/ $\mathrm{ru} /$ испания-начала-новый-крестовый-поход-против-неплательщиков-налогов/a-16765213(дата обращения - 03.12.2020).

5. Налоговая система Испании- URL: http://worldtaxes.ru/nalogi-v-evrope/nalogovaya-sistema-ispanii/(дата обращения -03.12.2020).

6. Налоги в Италии на доходы физических лиц (или подоходный налог) в Италии.- URL: https://egale. miaitalia.info/stati/61-nalog-na-dokhody-fizicheskikh-lits-ili-podokhodnyj-nalog-v-italii (дата обращения 03.12.2020).

7. Захарова А.В., Чернов С.Б. Совершенствование механизма налога на доходы физических лиц в Российской Федерации // АКТУАЛЬНЫЕ ПРОБЛЕМЫ УПРАВЛЕНИЯ - 2019.Материалы 24-й международной научнопрактической конференции.- М.: Государственный университет управления, 2020.- С. 64-68.

8. Президент «Баварии» Хёнес как зеркало налоговых дискуссий в Германии. - URL: https://www.dw.com/ru/ президент-баварии-хёнес-как-зеркало-налоговых-дискуссий-в-германии/а-16775192 (дата обращения 29.11.2019).

9. За 9 месяцев дифференциация населения по уровню доходов незначительно снизилась - Росстат. - URL: http://www.finmarket.ru/news/5107591 (дата обращения 30.03.2020).

10. Чернов С.Б. Совершенствование налогообложения доходов физических лиц как фактор вытеснения теневой экономической деятельности.- Россия: тенденции и перспективы развития. Ежегодник. Вып. 3. Часть 1.- М.: ИНИОН РАН, 2008. С. 467-471.

11. Гусаров С. «Меня самого это коробит»: Путин высказался о высоких зарплатах глав госкорпораций. - URL: https://russian.rt.com/russia/article/728083-putin-zarplaty-goskorporacii (дата обращения 30 марта 2020).

12. Налоги и налоговая система CША. - URL: https://zagranportal.ru/ssha/finansy-ssha/nalogi-v-ssha.html (дата обращения 30.03.2020).

13. Президент подписал закон о повышении ставки НДФЛ до 15\% с доходов более 5 млн. рублей. - URL: https:// www.nalog.ru/rn77/news/activities_fts/10216621/(дата обращения - 03.12.2020). 